\title{
Physical Conditioning of Freestyle Swimming Athletes
}

\author{
Alnedral $1^{*}$ and Bonardo Aritonang ${ }^{2}$ \\ 1,2Dep. of Coaching, Faculty of Sport Science, Universitas Negeri Padang, Padang, Indonesia \\ *Corresponding author. Email: alnedral@fik.unp.ac.id
}

\begin{abstract}
The problem in this study is the low performance of the TirtaKaluang swimming pool athletes in Padang. This study aims to determine the level of physical condition of athletes, including: explosive power leg muscles, flexibility, and speed.The design of this research is descriptive research. Sampling was done by purposive sampling technique, amounting to 13 people, 5 sons and 8 daughters in the achievement group. Explosive power of leg muscles was measured by standing broad jump test. Flexibility is measured by a flexiometer test. Running speed is used for 60 meter sprint tests. Data analysis techniques using descriptive statistics with frequency distribution in the form of percentages.The results of the study: (1) The level of explosive power of the athlete's leg muscles obtained an average value of $186.6 \mathrm{~cm}$ (son) and $133.0 \mathrm{~cm}$ (daughter) are in sufficient classification. (2) The level of flexibility of athletes obtained an average value of $10.8 \mathrm{~cm}$ (son) and $11.7 \mathrm{~cm}$ (daughter) are in the less classification. (3) The speed of the athlete obtained an average value of 9.9 seconds (son) and 12.1 seconds (daughter) are in the less classification.
\end{abstract}

\section{Keywords: Physical condition, swimming athlete}

\section{INTRODUCTION}

An extension of the swimming association and the spearhead of PRSI (Association of Pool Indonesia). Through swimming association, the community can get to know, learn and practice swimming. Thus, the swimming association grow and develop in the midst of people's lives is a place for people to practice swimming, both as achievement, recreation, as well as giving birth pendidikan.Untuk swimming athletes who excel in Padang then a variety of resources and efforts have best dilakukan.Prestasi on lately that has been achieved by the swimming association athlete TirtaKaluang Padang is 1 ranked female athlete in the 2017 provincial level events O2SN SD (National Student Sports Olympiad).

While it is for the athlete son can not obtain a medal at the number on the prestigious sports week. Meanwhile, in Porprov XIV 2016 in the city of Padang and Porprov XV in 2018 in Padang Pariaman regency is not a single person swimming association athlete Tirta Kaluang Padang to win the gold medal in the 50 meters freestyle. Loosening of associations athlete's performance Tirta Kaluang Padang swimming in the 50 meters freestyle necessarily be caused by various factors.

Sports activities are many contributing factors that influence to mndapatkan achievements, such as: physical, technical, tactical, and mental (Soniawan, 2018). In addition to an outdoor sport has physical, technical, tactical, and mental well also needed a good mastery of technique on the athletes, because without a good mastery of techniques that a person can not realize the athlete's performance.

Achieve peak performance then there are various factors that influence it. The factors that determine the achievement in the sport in the opinion of Syafruddin (2011) is "the physical ability, mastery of technique, tactics and mental abilities". Then it can be understood that a swimmer can achieve the best performance if he has a good physical ability, mastery of a good swimming technique, the ability to create strategies and tactics, as well as the mentality and practice. The four components of achievement existence influence each other, so it can notbe separated from one another. Thus, the four factors that affect the achievement must receive the training portion of proportion.

Based on the interviews the researchers did with coach Tirta Kaluang Padang on observations dated 10 April 2018, the researchers obtain information related to the process of training athletes. At this time athlete swimming association Tirta Kaluang Padang undergoing physical training preparation process for dealing with events such observations.Researchers noticed some problems related to the activity of 50 meter swimming pool freestyle athlete associations Tirta Kaluang Padang. The problems that occur in athletes swimming association Padang Tirta Kaluang latter should know the cause. These problems can interfere with the course of the exercise and of course, adversely impact the achievement of future athletes.

Studying the problems that occur in athletes Tirta Kaluang strong belief Padang then researchers closely related to the physical condition. Researchers strong 
suspicion that the physical condition of athletes association Tirta Kaluang Padang is on the degree or level is not maximized or low. With low physical condition then this causes the athlete associations Kaluang Tirta Padang has a record time of 50 meter freestyle swimming is still very far away from the national record. Therefore, to determine the level of the physical condition of athletes association Tirta Kaluang Padang is necessary to do an in-depth study. Based on these problems, researchers are interested to know the level of physical condition that is owned by the athlete the 50 meters freestyle swimming Tirta Kaluang Padang through a study.

In sports there are several techniques pool or swimming styles are studied and diperlombakan, among others: freestyle, breaststroke, backstroke and butterfly. Freestyle swimming technique is the style most in demand by the public and the swimmers. This is because freestyle is a style that is quite easy to master and is the fastest style of the existing four swimming styles. Opinion Thomas (2006) says "freestyle is esiensi of renang.Gaya This allows us to move faster in water than other styles like breaststroke, backstroke, and butterfly" . Sismadiyanto and Ermawan (2008) "characteristic of freestyle is: a rotating arm motion similar to the motion propeller and down movement rises crossed legs". Maidarman (2009) "freestyle swimming technique is highly efficient from the styles of swimming, because the hands and feet are used in different ways, which provide a break during the recovery phase". Hendromartono (1992) "freestyle (freestyle / crawl) is a style resembling an animal, and therefore called crawl that means crawling".

Based on some of these opinions can be understood that the technique is freestyle swimming style that has a very distinctive characteristic features compared with other swimming techniques. Freestyle movement has two major components of the dominant can be observed, among others, is the movement of the arm and leg movements. Arm movement freestyle swimming technique resembles the rotational velocity of the air propeller, while the movement of the legs is done by movements in cross punch. The role of the arms and legs to produce the same amount of thrust, so the freestyle swimming technique is the fastest swimming style compared to the butterfly, breaststroke and backstroke.

Physical condition Becomesone of the factors that affect the ability, appearance, and even the achievements of athletes in the sport. Therefore, physical condition cannot be ignored in the formation, developing an athlete's ability to achieve its peak. According Rahayu (2018) says that "physical condition is a special unit of the components that cannot be separated without either increase or maintenance." Meanwhile, according to Akbar, et al (2015) concluded "there is a positive relationship between sporting activity pool with physical fitness swimmer ". One element of the physical condition isexplosive powermuscle or more commonly also known as muscle explosive power that is one of the elements of the physical condition or abilities. Elements of explosive power is required by the sport, yakninya sports that require muscle's ability to cope with the load by directing maximum power and speed at the same time.According Budiarsa, et al (2014) "muscle explosive power is a combination of strength and speed or maximum muscle." So the explosive power of a blend or combination of power and speed to overcome the burden or obstacle to the pace of contraction is high. Muscle contraction is important in sports skills, how to work the muscles to produce movement. Such as: running, jumping, throwing, pushing and memukul.Hal Similar delivered by Pujo, (2015) explosive power is the product of strength and speed. This means that the ability of the muscle explosive power can be seen from the results of a monkey show performed by using the power and speed.

Based on theory above then explosive powerleg muscles can be defined as the ability of the leg muscles to cope with the direct imposition of the maximum strength of muscle contraction and takes place in a short time. In this case the load given to the leg muscles can generate a strong and rapid movement, for example is a jumping movement.Danardono, et al (2014) "there is a significant relationship between leg muscle power at a speed of 50 meters crawl swimming (free)".

If seen from the analysis start movement freestyle then start the movement is done by relying on the ability of impulse or repulsion foot against the starting blocks and assisted with the swing arm. The impetus for strong and fast from leg swimmer swimmers result can be pushed to the front, hovering in the air, into the water, and then slid in the water at a certain distance. For swimmers to maximize impulse (repulsion) with strong legs and quick this gives an advantage for him to be drifting towards the front as far as possible. Momentum of the strength and speed of repulsion legs can carry swimmers further body floating in the water and glide toward the front.

Flexibility is one component of physical condition is very important to consider the motion in an appearance, especially concerning the functional capacity of a joint. Syafruddin, (2011) said that "flexibility is the ability ankle / joint to be able to move to all direction with an amplitude of motion (range of motion) have broad and in accordance with the joint function-driven ". Arsil, (2009) "flexibility is the ability 
to move the joints and muscles in the overall room for maneuver".

Based on some of these opinions, it can be concluded that the flexibility of the body is the ability of all joints of the body to undertake the broadest possible movement (high amplitude) to perform a physical activity without injury. The primary key or hold a pivotal role in flexibility is a joints and muscles. The ability to move the joints in the body widely and all directions according to function and be assisted muscle elasticity (longer and shorter) determines the level of flexibility that is owned by someone.

According to Irrawaddy, (2014) "flexibility is influenced by: (a) The shape, the type and structure of the joints, (b) the level of elasticity, (c). Age, (d) Gender, (e) temperature, (f) muscle strength, and (g) Fatigue and emotional state ". Syafruddin, (2011) mentions that the ability is influenced by flexibility and anatagonis synergistic muscle coordination, joint form, the temperature of muscles, tendons and ligaments capabilities, age and gender.

Opinion Kurnia, (2001) "at the swimming sport, flexibility is needed even at a fairly high level". One role of flexibility in the sport can be seen swimming in the swimming movements 50 meter freestyle. 50 meter freestyle swimming is a physical activity that is classified in the category of short-distance sprints. A swimmer is all out (all out) will melakuka rotational movement of the arm and leg blows. In such situations it is needed the flexibility of the body, both joints of the arm, the skeleton joints, and the joints of the leg. All the joints of the body must be in a state of bending so that movement freestyle swimming can be carried out smoothly. If the body is not flexible so it can disturb the course of movement, resulting in the tempo of movements performed by the swimmer.

In the 50-meter freestyle swimming are also required elements of the physical condition of speed. Opinion Widiastuti, (2011) "speed is the ability to perform similar movements in a row in the shortest possible time, or the ability to travel a distance in the shortest possible time". MenuurtIsmayarti, (2008) "speed is one important biomotorika ability to do sports activities".

Based on these opinions can be understood that one of the factors that determine the rate of speed is a type of muscle fibers, both the speed of running and swimming speed. Someone who has the dominant type of white muscle fibers (fast twitch) will have better speed than someone who is dominant has the red muscle fibers. Both activities running and swimming activity, the dominant swimmer or runner that has a kind of white muscle fibers have a swim speed or running speed is better than the dominant swimmer has a kind of red muscle fibers. But it is certainly a swimmer or runner must master the technique of swimming or running the automation.

Based on the differences in types of muscle fibers, then the coach must refer to it in terms of selecting and defining the specification numbers in sports. The dominant athletes have matching white muscle fibers are trained on the numbers of short distances, such as the 50 meters freestyle. While the dominant athletes have more red muscle fibers suitable trained on numbers of medium-range and long-distance, such as the 400 meters, 800 meters and 1500 meters freestyle.

\section{RESEARCH METHODS}

This research is a descriptive study. The purpose of this study to determine the level of physical condition of athletes 50 meters freestyle swimming association Padang.Tempat City TirtaKaluang research conducted inLotus swimming pool area of Padang and the parking lot of the sports hall $\mathrm{H}$. AgusSalim Padang. This research was conducted on November 22 and January 23 2019saat hour exercise swimming association TirtaKaluang Padang. The population in this study is Tirta swimming association athlete Kaluang Padang totaling 33 people.Data collection techniques performed on the sample by using test the ability of the physical condition, which consists of three test items, namely, explosive leg muscle power measured by the standing broad jump test, measured by flexiometertest flexibility, and speed is measured with a test sprint 60 meters. The data analysis technique used is to use a percentage formula.

\section{RESULTS AND DISCUSSION}

\section{Explosive Power Leg muscles}

To answer the research questions of data collection and data analysis. Seteleh data collection and data analysis of the obtained results as contained in the frequency distribution table as follows: 
Table 1. Frequency Distribution Data Limb Muscle Power Explosive Athletes No. 50 Meter Freestyle Swimming Association TirtaKaluang Padang (Man Athletes)

\begin{tabular}{|l|l|l|l|}
\hline \multirow{2}{*}{ Class Interval $(\mathrm{cm})$} & \multicolumn{2}{c|}{ Frequency } & \multirow{2}{*}{ Relative (\%) } \\
\cline { 2 - 4 } & \multicolumn{1}{|c|}{ Absolut (fa) } & \multicolumn{2}{|c|}{} \\
\hline$>230.6$ & 0 & $0.0 \%$ & Very well \\
\hline 201.3 to 230.6 & 2 & $40.0 \%$ & Well \\
\hline 172.0 to 201.2 & 1 & $20.0 \%$ & Enough \\
\hline 142.7 to 171.9 & 2 & $40.0 \%$ & Less \\
\hline$<142.7$ & 0 & $0.0 \%$ & Less than Once \\
\hline Total & 5 & $100.0 \%$ & \\
\hline
\end{tabular}

Based on the data in the table can be briefed as follows: From 5 athletes son then $2(40.0 \%)$ had muscle power tingkatexplosivetungkaiyang are in good classification with the acquisition of a value ranging between 201.3 to $230.6 \mathrm{~cm}$. $1(20.0 \%)$ had muscle power tingkatexplosivetungkaiyang currently on klasifikasicukup with acquisition values ranging from 172.0 to $201.2 \mathrm{~cm} .2(40.0 \%)$ have high levels of explosive muscle power currently on with acquisition values ranging from 142.7 to $171.9 \mathrm{~cm}$. Based on the data analysis obtained by the average value of leg muscle explosive power athlete swimming association TirtaKaluang son Padang186,6 City cm.

Later measurements of leg muscle explosive power female athlete was also conducted to obtain data of explosive power leg muscle female athlete. For more details about the research results of explosive power of data limb muscle female athlete swimming association Tirta Kaluang Padang then it can be seen in the table following frequency distribution and histogram.

Table 2. Frequency Data Distribution Power Muscle Limb Explosive Athletes No. 50 Meter Freestyle Swimming Association TirtaKaluang Padang (WomanAthletes)

\begin{tabular}{|c|c|c|c|}
\hline \multirow{2}{*}{ Class Interval $(\mathrm{cm})$} & \multicolumn{2}{|c|}{ Frequency } & \multirow{2}{*}{ Classification } \\
\cline { 2 - 4 } & Absolut (fa) & Relative (\%) & Very well \\
\hline$>162.9$ & 0 & $0.0 \%$ & Well \\
\hline 143.0 to 162.9 & 3 & $37.5 \%$ & Enough \\
\hline 123.1 to 142.9 & 1 & $12.5 \%$ & Less \\
\hline 103.2 to 123.0 & 4 & $50.0 \%$ & Less than Once \\
\hline$<103.2$ & 0 & $0.0 \%$ & \\
\hline Total & 8 & $100.0 \%$ & \\
\hline
\end{tabular}

Based on the data in the table can be briefed as follows: From 8 female athlete then $3(37.5 \%)$ had muscle power tingkatexplosivetungkaiyang are in good classification with the acquisition of a value ranging between 143.0 to $162.9 \mathrm{~cm} .1 \quad(12.5 \%)$ had muscle power tingkatexplosivetungkaiyang currently on klasifikasicukup with acquisition values ranging from 123.1 to $142.9 \mathrm{~cm}$. $4(50.0 \%)$ had muscle power tingkatexplosivetungkaiyang klasifikasikurang with acquisition values ranging from 103.2 to $123.0 \mathrm{~cm}$. Based on the data analysis obtained by the average value of leg muscle explosive power female athlete swimming association TirtaKaluang Padang133,0 City $\mathrm{cm}$.

\section{Flexibility (Flexibility)}

To answer the research questions of data collection and data analysis. 
Table 3. Frequency Distribution Data Flexibility Athletes No. 50 Meter Freestyle Swimming AssociationTirtaKaluang Padang (Man Athletes)

\begin{tabular}{|c|c|c|c|}
\hline \multirow{2}{*}{ Class Interval $(\mathrm{cm})$} & \multicolumn{2}{|l|}{ Frequency } & \multirow{2}{*}{ Classification } \\
\hline & Absolut (fa) & Relative (\%) & \\
\hline$>24$ & 0 & $0.0 \%$ & Very well \\
\hline $18-23$ & 0 & $0.0 \%$ & Well \\
\hline $12-17$ & 3 & $60.0 \%$ & Enough \\
\hline $6-11$ & 1 & $20.0 \%$ & Less \\
\hline $1-5$ & 1 & $20.0 \%$ & Very less \\
\hline Total & 5 & $100.0 \%$ & \\
\hline
\end{tabular}

Based on the information in the frequency distribution table, it can be briefed as follows: From 5 samples of the three persons $(60.0 \%)$ had a degree of flexibility capabilities are in good classification with the acquisition of a value ranging between $12-17 \mathrm{~cm} .1$ $(20.0 \%)$ have a level of flexibility that are in the classification ability enough with the acquisition of a value ranging between $6-11 \mathrm{~cm} .1(20.0 \%)$ had a degree of flexibility is at klasifikasikurang capabilities with the acquisition of a value ranging between $1-5 \mathrm{~cm}$. Based on the data analysis obtained by the average value of flexibility athlete son sebesar10,8 cm. If the numbers are interpreted into tables flexibility assessment norms then the number is included into klasifikasikurang.

Then the flexibility measurements were also conducted on female athlete using flexiometer test. Testersebutdilakukan aims to get the data flexibility female athlete. For more details of data flexibility Association female athlete Pool Tirta Kaluang Padang then it can be seen in the frequency distribution table and the image histogram rod as follows:

Table 4. Frequency Distribution Data Flexibility (flexibility) Athletes No. 50 Meter Freestyle Swimming Association TirtaKaluang Padang (Woman Athletes)

\begin{tabular}{|c|c|c|c|}
\hline \multirow{2}{*}{ Class Interval $(\mathrm{cm})$} & \multicolumn{2}{|l|}{ Frequency } & \multirow{2}{*}{ Classification } \\
\hline & Absolut (fa) & Relative (\%) & \\
\hline$>24$ & 1 & $12.5 \%$ & Very well \\
\hline $19-23$ & 2 & $25.0 \%$ & Well \\
\hline $12-18$ & 0 & $0.0 \%$ & Enough \\
\hline $7-11$ & 1 & $12.5 \%$ & Less \\
\hline $2-6$ & 4 & $50.0 \%$ & very Once \\
\hline Total & 8 & $100.0 \%$ & \\
\hline
\end{tabular}

Based on the information in the frequency distribution table, it can be briefed as follows: From the 8 sample then $1(12.5 \%)$ had a degree of flexibility is at klasifikasisempurna capabilities with the acquisition of nilaibesar of $24 \mathrm{~cm} .2(25.0 \%)$ had a degree of flexibility is at klasifikasibaik capabilities with the acquisition of a value ranging between $19-23 \mathrm{~cm} .1$ $(12.5 \%)$ had a degree of flexibility is at klasifikasikurang capabilities with the acquisition of a value ranging between $7-11 \mathrm{~cm} .4(50.0 \%)$ had a degree of flexibility capabilities are at klasifikasisangat less with the acquisition of a value ranging between 2-6 $\mathrm{cm}$.Berdasarkan of data analysis obtained by the average value flexibility sebesar $11,7 \mathrm{~cm}$ female athlete.

\section{Speed}

To answer the research questions of data collection and data analysis. 
Table 5. Frequency Distribution Athletes Speed Data Number 50 Meter Freestyle Swimming Association TirtaKaluang Padang (ManAthletes)

\begin{tabular}{|c|c|c|c|}
\hline \multirow{2}{*}{ Class Interval (seconds) } & \multicolumn{2}{|l|}{ Frequency } & \multirow{2}{*}{ Classification } \\
\hline & Absolut (Fa) & Relatively(\%) & \\
\hline $\mathrm{sd}-7.2$ & 0 & $0.0 \%$ & Very well \\
\hline 7.2 to 8.3 & 1 & $20.0 \%$ & Well \\
\hline 8.4 to 9.6 & 2 & $40.0 \%$ & Enough \\
\hline 9.7 to 11.0 & 1 & $20.0 \%$ & Less \\
\hline $11.1-\mathrm{ff}$ & 1 & $20.0 \%$ & Less than Once \\
\hline Total & 5 & $100.0 \%$ & \\
\hline
\end{tabular}

based on information in the histogram on the previous page, it can be briefed as follows: From 5 samples known to one person $(20.0 \%)$ had levels of speed running with the acquisition time (value) ranged from 7.2 to 8.3 seconds included in the classification well. 2 People $(40.0 \%)$ had levels of speed running with the acquisition time (value) ranged from 8.4 to 9.6 seconds included in the classification enough. 1 People
$(20.0 \%)$ had levels of speed running with the acquisition time (value) ranged from 9.7 to 11.0 seconds included in the classification less. 1 People $(20.0 \%)$ had levels of speed running with the acquisition time (value) of 11.1 seconds and so included in the classification of less sekali.Berdasarkan of data analysis obtained by the average value of the speed of running with the acquisition value of 9.9 seconds.

Table 6. Distribution Frequency Athletes Speed Data Number 50 Meter Freestyle Swimming Association TirtaKaluang Padang (WomanAthletes)

\begin{tabular}{|c|c|c|c|}
\hline \multirow{2}{*}{ Class Interval (seconds) } & \multicolumn{2}{|c|}{ Frequency } & \multirow{2}{*}{ Classification } \\
\hline & Absolut (Fa) & Relatively(\%) & \\
\hline sd -8.4 & 0 & $0.0 \%$ & Very well \\
\hline 8.5 to 9.8 & 0 & $0.0 \%$ & Well \\
\hline 9.9 to 11.4 & 2 & $25.0 \%$ & moderate \\
\hline 11.5 to 13.4 & 5 & $62.5 \%$ & Less \\
\hline $13.5-\mathrm{ff}$ & 1 & $12.5 \%$ & less so \\
\hline Total & 8 & $100.0 \%$ & \\
\hline
\end{tabular}

Based on the information in the frequency distribution tables and histograms on the previous page, it can be briefed as follows: From 8 samples known to two people $(25.0 \%)$ had levels of speed running with the acquisition time (value) ranging from 9.9 to 11,4 seconds included in the classification enough. 6 People $(62.5 \%)$ had levels of speed running with the acquisition time (value) ranged from 11.5 to 13.4 seconds included in the classification less. 1 People $(12.5 \%)$ had levels of speed running with the acquisition time (value) of 13.5 seconds and so included in the classification of less sekali.Berdasarkan of data analysis obtained by the average value of the speed of running with the acquisition value of 12.1 seconds.
Discussion

1. explosive Power Leg muscles

From the analysis dataexplosive limb muscle power athletes the 50 meters freestyle swimming association TirtaKaluang Padang obtained an average value of $186.6 \mathrm{~cm}$ for male athletes and $133.0 \mathrm{~cm}$ for the female athlete. If nilai186,6 $\mathrm{cm}$ for the female athlete interpreted into assessment norms that value will be at sufficient classification. So also with the value of 133.0 $\mathrm{cm}$ (for the female athlete) if interpreted in the assessment norms on the classification of the scores fall enough. Thus it can be concluded that the level of explosive Events limb muscle power athletes the 50 meters freestyle swimming association TirtaKaluang Padang are in sufficient classification.

Based on biomechanical motion analysis and the role of leg muscle explosive power on the 50 meter 
freestyle swimming can mainly be seen when the swimmer to start. At the time of the swimmers start trying to jump as far as possible towards the front after hearing the cue start of the starter with a strong movement.Start expected by each swimmer is how he was able to start well and correctly, it is characterized by its ability to can jump as far as possible towards the front in accordance with the regulations start. To be able to jump as far as possible can only be realized if the leg muscles to contract in explosive athletes (strong and fast). AsZimmermann opinion of the Irrawaddy (2014) said "Explosive power is the ability to move the body or body portion is strong at high speed".

\section{2. flexibility (Flexibility)}

From the analysis of dataflexibility (flexibility) athletes the 50 meters freestyle swimming association TirtaKaluang Padang obtained an average value of 10.8 $\mathrm{cm}$ for male athletes and $11.7 \mathrm{~cm}$ for female athlete. If nilai10,8 $\mathrm{cm}$ (for male athletes) are interpreted into assessment norms that value. Likewise with a value of $11.7 \mathrm{~cm}$ (for the female athlete) if interpreted into assessment norms that value will be at klasifikasikurang. Thus it can be concluded that the level of Events flexibility (flexibility) athletes the 50 meters freestyle swimming association TirtaKaluang Padang.

Opinion Irrawaddy (2014) "Without a good flexibility, difficult to do a perfect movement in addition to limiting the performance quality of motion". Opinion Kurnia (2001) "at the swimming sport, flexibility is needed even at a fairly high level".Of that argument, it can be believed that the conditions of flexibility is needed by every swimmer. Based on the theory of flexibility, it can be concluded that flexibility is an element of physical condition that becomes the deciding factor for a person in control of a movement / skill, increase strength, improve agility, and manage the coordination. Therefore, the coach of the swimming association TirtaKaluang Padang in order to make the study's findings as information and evaluation materials.

\section{Speed}

From the analysis of the athlete datakecepatan the 50 meters freestyle swimming association Tirta Kaluang Padang obtained an average value of 9.9 seconds for the athlete's son and 12.1 seconds for the female athlete. If nilai9,9 $\mathrm{cm}$ (for male athletes) are interpreted into assessment norms that value will be at less classification.

So also with the value of 12.1 seconds (for a female athlete) if interpreted into assessment norms that value will be at klasifikasikurang. Thus it can be concluded that the level of athletes speed kodisi the 50 meters freestyle swimming association TirtaKaluang Padang are in less classification.
Speed condition is an element of the physical conditions required in the swimming sport. According to Lutan, et al (1991) say that the speed condition is a component of the required physical abilities in the swimming sport. Based on these opinions, it can be understood that the element is one of the conditions of the physical conditions required in the swimming sport. Given this, the condition of the speed in swimming athletes must be in excellent condition. Without having adequate speed conditions, it is difficult for a swimmer to get the fastest time on the acquisition of certain numbers, one of which is the 50 meters freestyle.

\section{CONCLUSIONS AND SUGGESTIONS}

Based on the research that has been described in the previous chapter can be stated conclusion that the average level of the physical condition of athletes the 50 meters freestyle bevy of bathing TirtaKaluang Padang consisting of explosive power leg muscle, flexibility (flexibility), and the speed is in the category of less, then it should be given the proper training so that the physical condition of athletes increases.

\section{REFERENCES}

[1] Arsil. 2009. Development of Physical Condition. Padang: Nikken UNP.

[2] Akbar, et al. 2015. Relation Activities Swimming Sports Clubs Arowana Against Physical Fitness, Performance Pool, And Academic Achievement. (Journal.Student.uny.ac.id, sports coaching education S-1, Vol. 1.No. 1 Issue January 2015).

[3] Budiarsa, et al. (2014). "Effect of Training Single Leg Hops against Explosive Muscle Strength and Power Limbs". e-Journal of Sport Science Ganesha Education University. Vol I. No. 1, September 2014.

[4] Danardono, et al. 2014. Relationship Between Long Legs, Muscle Power Limbs, And Frequency Limb Movement Speed With 50 Meter Pool Selabora KU Students Crawl Style IV. (Jurnal.student.uny.ac.id, sports coaching Education S-1, Volume.1 1 Edition August 2014).

[5] Hendromartono, Soejoko.1992. Sports Picks Pool. Jakarta: Department of Education and the Director General of Higher Education.

[6] Irawady, Hendri. 2014. Physical Condition and Measurement. Padang: UNP Press.

[7] Kurnia, Dadeng. Fostering 2001. Basic guidelines Swimming Sports Achievement. Jakarta: PB. PRSI

[8] Lutan, Rush et al. 1991. People and Sports. Bandung: ITB cooperation and FPOK / Teachers' Training Bandung.

[9] Maidarman. 2009. Teaching Swimming. Padang: Nikken Padang State University. 
[10] Pujo, DanangBroto. (2015). "Effect of Exercise Pliometrics against Limb Muscle Power of Youth Athletes volleyball". Journal Motion. Vol VI. No. 2, September 2015. 174-185.

[11] Rahayu, Neng. (2018). "The level of PencakSilat Athletes Physical Condition Padepokan PSHT PSHT in Tulungagung." Journal Simki-Techsain. Vol II. No. 5, February 2018, Page 1-12.

[12] Sismadiyantoand ErmawanSusanto. 2008. Basic Motion Pool. Yogyakarta: FIK UNY.

[13] Soniawan, V. Methods of Playing Against Influential Long Passing Ability Football.

[14] Sukmadinata, Nana Syaodih. 2010. Methods of Education. Bandung: Graduate School of Education UiversitasIndonesaiWith PT Youth Rosdakarya.

[15] Syafruddin. 2011. Sports Coaching Basics. Padang: Nikken UNP.

[16] Thomas, David G. 2006. Pool Beginner. Jakarta: King Grafindo Persada.

[17] Widiastuti. 2011. Test and Measurement Sport. Jakarta: PT BumiTimur Jaya. 